\title{
Soil microaggregate and macroaggregate decay over time and soil carbon change as influenced by different tillage systems
}

\author{
M.M. Al-Kaisi, A. Douelle, and D. Kwaw-Mensah
}

\begin{abstract}
Soil tillage can affect the formation and stability of soil aggregates. The disruption of soil structure weakens soil aggregates to be susceptible to the external forces of water, wind, and traffic instantaneously, and over time. The choice of tillage system or land management changes the soil physical condition and soil organic matter content, which is an essential factor in building soil aggregates. This study was conducted to investigate the effects of different tillage systems on the rate of decay of different sizes of soil aggregate fractions and other associated properties over time as subjected to a continuous wetting process. This research was conducted on a long-term tillage study, established in 2002 at the Iowa State University Agronomy Research Farm near Ames, Iowa. The soil association in this study is Clarion-Nicollet-Webster (Clarion [fine-loamy, mixed, mesic, Typic Hapluduolls], Nicollet [fine-loamy, mixed, mesic, Aquic Hapluduolls], and Webster [fine-loam, mixed, mesic, Typic Endoaquolls]). The experimental design was a randomized complete block design with four replications. Main plot treatments were five tillage systems: moldboard-plow, chisel-plow, deep-rip, strip-till, and no-till. The cropping system was corn (Zea mays L.)soybean (Glycine max L.) rotation. Wet aggregate stability was measured using the Wet Sieving Apparatus (Eijkelkamp, Agrisearch Equipment. Art no. 08.13). Soil organic carbon (SOC) and soil total nitrogen $(\mathrm{N})$ were analyzed by dry combustion using CHN Analyzer (TruSpec CHNVersion 2.5x). Results show no-till with the highest carbon (C) content and the highest macro- and microaggregate stability over time. The findings also show a strong relationship between the increase in SOC content and the stability of macro- and microaggregate under continuous wetting process. Furthermore, the findings suggest that aggregate stability and moisture content are highly correlated with SOC content, and the rate of decay of both aggregate sizes (macro and micro) is highly influenced by the intensity of tillage. The implication of this research is the importance of no-till not only in increasing the stability of micro- and macroaggregates and SOC storage, but also in its effect on increasing the stability of all aggregate fractions in continuous wet conditions for extended periods of time.
\end{abstract}

Key words: aggregate stability—carbon—nitrogen—organic matter— soil moisture—tillage systems

Soil aggregate stability and its resilience under continuous wetting intensity can be affected by tillage intensity and crop rotation among many factors that influence soil carbon (C) pool size and quality (Al-Kaisi and Yin 2005). Tillage system and crop rotation are essential factors in agricultural systems that influence soil fertility and the formation of soil aggregates (Saljnikov et al. 2013). The stability of soil aggregates defines soil structure and influences crop development. A good soil structure has a stable aggregate fraction that tolerates different of water and nutrient supplies during the early growth stages of the plant (Donald et al. 1987). Soil aggregates do not only protect soil organic matter but also influence nutrient cycling, seedling emergence, and root development (Díaz-Zorita et al. 2005). It has been documented that no-till has greater macroaggregates ( 2 to $0.5 \mathrm{~mm}$ [0.0787 to 0.0197 in]) than conventional tillage (Guzman and Al-Kaisi 2011; Gathala et al. 2011; Wright et al. 2010). Generally, the increase in large aggregates in no-till soils is the result of the presence of large amounts of crop residue on the soil surface and minimum soil disturbance, which facilitates soil structural stability. Soil macroaggregates are held by a network of fine roots and fungal hyphae (Curaqueo et al. 2010), which suggests that macroaggregates are readily disrupted by tillage. Therefore, a higher proportion of macroaggregate in soils is indicative of less physical disturbance. Under no-till, crop residue decomposes at a slower rate, leading to the gradual build-up and an increase in the soil organic carbon (SOC) and microbial activity (De Sanctis et al. 2012). The resulting substrate from residue decomposition contributes to stabilizing soil aggregates (Six et al. 2004; Wright and Anderson 2000). In addition to improving soil aggregate stability, organic matter can enhance nutrient availability to plants and also improve the hydrothermal capacity of the soil (Gavriliev 2003). No-till soils have greater aggregate stability and greater $\mathrm{C}$, nitrogen $(\mathrm{N})$, and phosphorus $(\mathrm{P})$ concentrations in large $(>2$ $\mathrm{mm}[0.0787 \mathrm{in}])$ and small macroaggregates (0.21 to $2 \mathrm{~mm}$ [0.0083 to $0.0787 \mathrm{in}])$ than in microaggregates $(<0.21 \mathrm{~mm}$ [0.0083 in]) than chisel plow soils regardless of cropping system (Green et al. 2005). Improvement in soil organic matter under no-till has been documented in many long-term studies. In one study, no-till increased soil organic matter in the top $15 \mathrm{~cm}$ ( 6 in) by $18 \%$ after 13 years compared with conventional tillage (Beare et al. 1994). The question is how this increase in soil organic content can influence the stability of different soil aggregate

Mahdi M. Al-Kaisi is a professor in the Department of Agronomy at lowa State University in Ames, lowa. Adrien Douelle is a field agronomist with John Deere in Quebec, Canada. David Kwaw-Mensah is a research associate in the Department of Agronomy at lowa State University in Ames, lowa. 
factions over time when soil is subjected to continuous and high intensity of rain for extended period of time. The amount and storage of SOC in different soil aggregate fractions is highly influenced by the intensity of tillage system and cropping systems. Generally, no-till and conservation tillage may increase SOC concentration in the top soils depth (Reijneveld et al. 2005; Ismail et al. 1994). The influence of different tillage systems on the rate of decay of aggregate fractions needs to be examined in the context of tillage systems' effects on a host of soil physical, biological, and chemical properties, where soil organic matter affects these properties directly or indirectly. The interaction effect of tillage and crop rotation on soil biological and physical properties, including soil thermal and water holding capacity, is well documented (Perez-Brandán et al. 2012; Guzman and Al-Kaisi 2011). Crop residue is an important factor in improving soil quality, including soil aggregate stability and water content, within conservations systems as documented in many studies (Dam et al. 2004). We hypothesized that intensive tillage reduces SOC concentration and soil aggregate stability and increases rate of aggregates decay under continuous wet condition. The objective of this study was to evaluate the effect of five tillage systems on soil aggregate stability, decay rate over time, and associated SOC concentration under a continuous wetting process.

\section{Materials and Methods}

Site Description and Experimental Design. This study was conducted in 2011 in a longterm tillage experiment established in 2002 on the Iowa State University Agronomy Research Farm located at $42^{\circ} 01^{\prime} 20.32^{\prime \prime} \mathrm{N}$, $93^{\circ} 46^{\prime} 36.43^{\prime \prime} \mathrm{W}$, approximately $16 \mathrm{~km}(9.94$ mi) west of Ames, Iowa. The soil association is Clarion-Nicollet-Webster, (Clarion [fineloamy, mixed, mesic, Typic Hapluduolls], Nicollet [fine-loamy, mixed, mesic, Aquic Hapluduolls] and Webster [fine-loam, mixed, mesic, Typic Endoaquolls]). The study consisted of five tillage systems: no-till (NT), strip till (ST), chisel plow (CP), deep rip (DR), and moldboard plow (MP). All tillage treatments were established in the fall following the harvest of the previous crop. The CP treatment was implemented with a commercially available model with straight shanks and twisted chisel plow sweeps at the bottom mounted on a tool bar. The shanks were mounted on four tool bars in a stagger- ing order to ensure an effective spacing of 30 $\mathrm{cm}$ (12 in) between shanks for 22 to $25 \mathrm{~cm}$ (8.66 to 9.84 in) tillage depth. The ST treatment was 20 (7.87 in) cm deep, established with an anhydrous knife centered between two cover disks $20 \mathrm{~cm}$ (7.87 in) apart. The tilled zone was $20 \mathrm{~cm}$ (7.87 in) wide and 10 $\mathrm{cm}$ (3.94 in) deep in close proximity to the previous row. The DR treatment was established with a commercially available model with four straight shanks spaced at $76 \mathrm{~cm}$ (30 in) apart on a $3 \mathrm{~m}$ long (9.84 ft) (three points) tool bar. The effective tillage depth of the DR treatment with the straight shanks was $46 \mathrm{~cm}$ (18.11 in). The MP treatment was also established with a commercially available model with four full bottoms $46 \mathrm{~cm}$ (18.11 in) wide and $25 \mathrm{~cm}$ (9.84 in) deep. The MP treatment resulted in a complete inversion of the soil surface with nearly $100 \%$ incorporation of crop residue. All tillage treatments except NT and ST received one spring field cultivation $10 \mathrm{~cm}$ (3.94 in) deep prior to planting. Nitrogen was applied in the form of $32 \%$ urea $\left(\mathrm{CH}_{4} \mathrm{~N}_{2} \mathrm{O}\right)$ ammonium $\left(\mathrm{NH}_{4}\right)$ nitrate $\left(\mathrm{NO}_{3}\right)$ (UAN) in the spring for the corn (Zea mays L.) crop at planting and as a side dress postemergence. The $32 \%$ UAN side dress was injected between the rows at the rate of $135 \mathrm{~kg} \mathrm{ha}^{-1}\left(120.4 \mathrm{lb} \mathrm{ac}^{-1}\right)$ using a mole knife with two cover disks. The experimental design used in this study was a randomized complete block design with split plot arrangement, where tillage was the main treatment and crop rotation (corn and soybean [Glycine $\max$ L.]) is subplot in four replications. Plot dimensions were $27.4 \mathrm{~m}$ (90 ft) long and 9.1 $\mathrm{m}$ (30 ft) wide. The plots were split in two halves with the same tillage as main treatment. A cropping system of corn and soybean rotation $(\mathrm{C}-\mathrm{S})$ was adopted for this study.

Wet Aggregate Stability Determination. Soil samples were collected from each tillage treatment prior to harvest for the top 0 to 15 $\mathrm{cm}$ (0 to 6 in) depth. A golf course hole-cutter with the diameter of $10.5 \mathrm{~cm}$ (4.13 in) and depth $16 \mathrm{~cm}$ (6.3 in) was used to collect three soil aggregate samples per plot from each of four replications. This tool allows for quick and consistent soil depth sampling. Soil samples were stored in a cooler to maintain soil moisture during transfer to the laboratory for processing. The three soil samples per plot were subsequently sieved through an $8 \mathrm{~mm}(0.315$ in) sieve and air-dried for two to three days.

The wet aggregate stability of the three soil samples were determined by using the Wet Sieving Apparatus (Eijkelkamp Agrisearch Equipment Art no. 08.13, Giesbeek, Netherlands), which determines wet aggregate stability of soil as a function of water resistance. The sieves sizes used in this study are $2,1,0.5,0.25$, and $0.053 \mathrm{~mm}$ (0.0787, 0.0394, 0.0197, 0.0098, and 0.0021 in) to determine the two aggregate size fractions ranges of macroaggregates $(2,1$, and $0.5 \mathrm{~mm}$ [0.0787, 0.0394, and $0.0197 \mathrm{in}])$ and microaggregates $(0.25$ and $0.053 \mathrm{~mm}$ [0.0098 and 0.0021 in]) of each soil sample.

For each sieve, $4 \mathrm{~g}$ (0.14 oz) of air-dried $8 \mathrm{~mm}$ (0.315 in) sieved soil was weighed $( \pm 0.05 \mathrm{~g}[ \pm 0.0018 \mathrm{oz}])$. Prior to placing the sieves with the soil samples in the wet sieving apparatus, the soil was moistened with distilled water using a fine mist and left for five minutes to avoid air entrapment during shaking of the samples. After five minutes, the sieves with soil were transferred to the wet sieving apparatus (Eijkelkamp Agrisearch Equipment, Art no. 08.13), where metal containers each measuring $133.6 \mathrm{~cm}^{3}(6.10 \mathrm{~cm}$ inner diameter and $4.57 \mathrm{~cm}$ depth $\left[8.15 \mathrm{in}^{3}\right.$; 2.4 in inner diameter and 1.8 in depth]) below each sieve were filled with distilled water until each soil sample was inundated. The soil samples on the sieves were vertically oscillated in the distilled water-filled metal containers at the rate of 34 oscillations per minute. The dissolved soil aggregates resulting from the shaking process were collected in the metal containers of each sieve size. After shaking was completed for each time period, the wet sieving apparatus was stopped and the content (water plus dissolved aggregates) of each metal container was transferred to a glass container. The tray that holds the sieves was placed back at its original position in the wet sieving apparatus, and each metal container was refilled with distilled to start the next shaking period. This process was repeated on the same soil sample for the following times intervals: 3, 6, 12, 24, 48, 72, $96,120,144,168,192,216$, and $240 \mathrm{~min}-$ utes. The content of each glass container was oven-dried at $104^{\circ} \mathrm{C}\left(219^{\circ} \mathrm{F}\right)$ for 24 hours. After oven-drying, each glass container with its oven-dried contents was weighed using a Denver Instrument M-22 balance to obtain the weights of nonstable soil aggregates that passed through each respective sieve size for each time interval.

Calculation of Aggregate Stability. The percentage of stable aggregates was calculated using the following relationship: 
Stable aggregate $(\%)=\left\{\mathrm{W}_{\mathrm{i}}-\Sigma\left[\mathrm{W}_{\mathrm{t} 1}+\mathrm{W}_{\mathrm{t} 2}\right.\right.$ $\left.\left.+\ldots \mathrm{W}_{\text {tn }}\right] \div \mathrm{W}_{\mathrm{i}}\right\} \times 100$,

where $\mathrm{W}_{\text {in }}$ is the initial soil sample weight used (4 $\mathrm{g}[0.14 \mathrm{oz}]), \mathrm{W}_{\mathrm{t} 1}$ is the soil weight collected in container after first 3 minutes, and $\mathrm{W}_{\mathrm{tm}}$ is soil weight collected after last time period (240 minutes). All calculations were based on oven dry weight of samples. Aggregate stability percentages for both macro and microaggregate fractions were calculated for each replication and tillage treatment. Macroaggregate stability percentage over time was determined by using the average of 2,1 , and $0.5 \mathrm{~mm}(0.0787$, 0.0394 , and $0.0197 \mathrm{in}$ ) aggregate fractions. The microaggregates stability percentage was determined by using the average of 0.25 and 0.053 $\mathrm{mm}$ (0.0098 and $0.0021 \mathrm{in})$ aggregate fractions.

Soil Organic Carbon, Organic Nitrogen, $\boldsymbol{p H}$, and Bulk Density. Ten to twelve soil cores with $1.7 \mathrm{~cm}$ (0.7 in) diameter were randomly taken to the depth of 0 to $15 \mathrm{~cm}$ ( 0 to 6 in) in each plot, where three separate samples were collected per plot of each tillage system from four replications. Baseline soil samples for SOC concentration were collected prior to tillage treatments establishment in 2002 from each plot and four replications. The soil samples were sieved through a $2 \mathrm{~mm}$ (0.0787 in) sieve and air-dried before analyzing for $\mathrm{pH}$ (1:1; soil:water) using an AR15 pH meter (Accumet Research, Fisher Scientific International Inc.). The SOC and STN determined by dry combustion using $\mathrm{CHN}$ analyzer (TruSpec CHN Version 2.5×, LECO, St. Joseph, Michigan). Three soil bulk density samples were randomly collected from each plot at 0 to $15 \mathrm{~cm}$ (0 to 6 in) depth collecting three cores per subsample using a $1.7 \mathrm{~cm}$ (0.67 in) inner diameter soil probe. Bulk density samples were oven-dried at $104^{\circ} \mathrm{C}\left(219^{\circ} \mathrm{F}\right)$ for 24 hours and weighed. Bulk density value $\left(\mathrm{g} \mathrm{cm}^{-3}\right)$ for each sample was calculated as the oven-dry weight divided by the soil core volume (Blake and Hartge 1986).

Soil Moisture. Soil moisture was measured using the Field Scout TDR 100 (Spectrum technologies, Plainfield, Illinois), which determines volumetric soil moisture content on weekly basis after planting through the growing season at $15 \mathrm{~cm}$ (6 in) soil depth between rows for each tillage treatment. Three points of moisture measurements were taken for each plot within each replication. Averages of soil moisture per plot were used in the analysis. In addition, daily precipitation was recorded at a nearby weather station at the research farm.

\section{Figure 1}

Wet soil (a) microggregate ( 0.053 to $0.25 \mathrm{~mm}$ ) and (b) macroaggregate (0.5 to $2 \mathrm{~mm}$ ) stability percentage at 3 and 240 minutes of wet sieving of the top $15 \mathrm{~cm}$ of different tillage systems of a 10 year long-term tillage and crop rotation study.

(a)

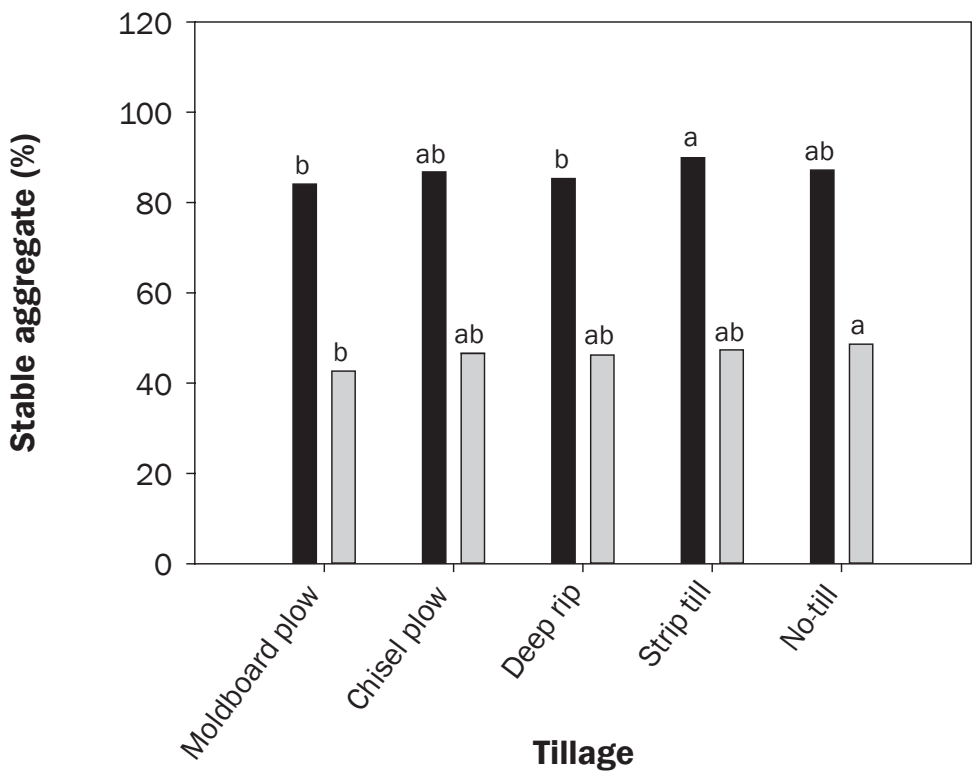

(b)

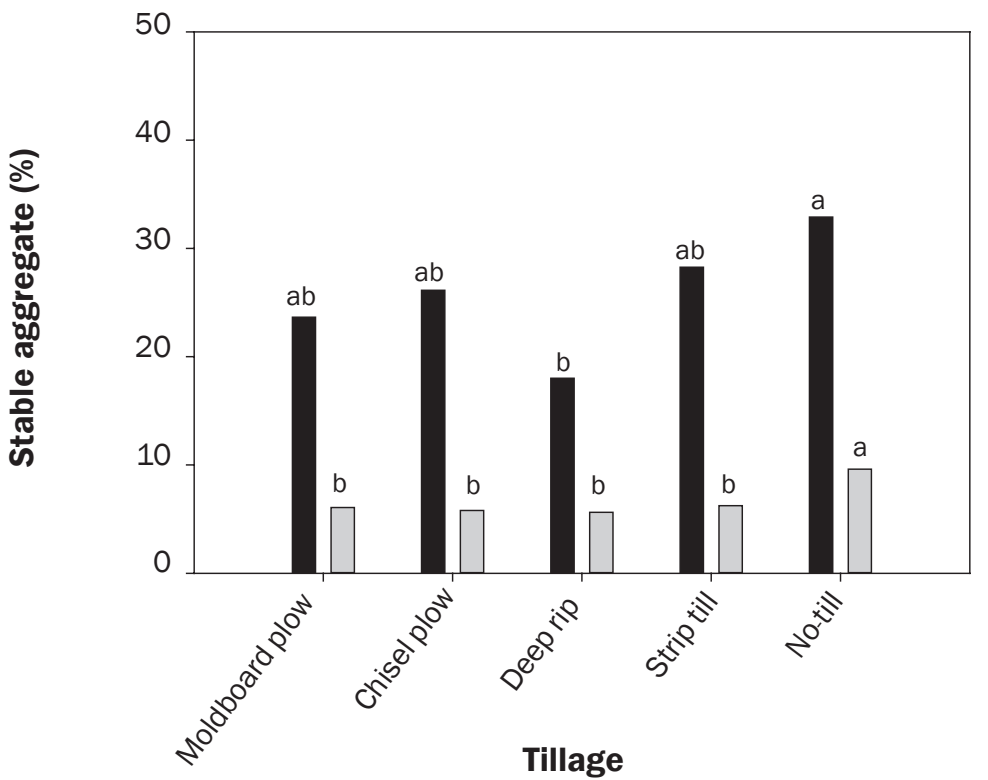

\section{Legend}

$\square 3$ minutes $\square 240$ minutes

Statistical Analysis. Data was analyzed using the general linear procedure (GLM) (SAS Institute Inc. 2002). Means were separated using the least squares means (LSM) when treatment effects were significant. Statistical significance was evaluated at $p \leq 0.05$.

\section{Results and Discussion}

Kinetics of Aggregate Stability. The stability of both micro and macroaggregates under different tillage systems at the initial wet sieving of 3 minutes and after 240 minutes is presented in figure $1 \mathrm{a}$ and $1 \mathrm{~b}$. Regardless of the tillage 


\section{Table 1}

Decay function for micro- and macroaggregates parameters $\left(y=b x^{a}\right)$ under continuous wet sieving.

\begin{tabular}{lllll}
\hline Fraction size $^{*}$ & Tillage & $\mathbf{a}$ & $\mathbf{b}$ & $\boldsymbol{r}^{\mathbf{2}}$ \\
\hline Microaggregares & MP & $-0.29 \mathrm{a}$ & 87.55 & 0.99 \\
& CP & $-0.27 \mathrm{a}$ & 92.84 & 0.98 \\
& DR & $-0.26 \mathrm{a}$ & 89.33 & 0.99 \\
& ST & $0.27 \mathrm{a}$ & 94.75 & 0.99 \\
& NT & $-0.25 \mathrm{a}$ & 93.48 & 0.98 \\
\hline Macroaggregates & MP & $-0.47 \mathrm{~b}$ & 18.33 & 0.91 \\
& CP & $-0.59 \mathrm{~b}$ & 24.54 & 0.99 \\
& DR & $-0.43 \mathrm{~b}$ & 15.33 & 0.94 \\
& ST & $-0.58 \mathrm{~b}$ & 24.78 & 0.97 \\
& NT & $-0.46 \mathrm{~b}$ & 30.05 & 0.98 \\
\hline
\end{tabular}

*Fraction size: microaggregate (0.053 to $0.25 \mathrm{~mm})$; macroaggregates ( 0.5 to $2 \mathrm{~mm}$ ).

Notes: a values with the same letter are not significantly different at $p<0.05$. MP $=$ moldboard plow. $\mathrm{CP}=$ chisel plow. $\mathrm{DR}=$ deep ripper. $\mathrm{ST}=$ strip tillage. $\mathrm{NT}=$ no-tillage.

system, the tolerance of aggregates to initial disruptive forces of water was much lower with macroaggregates with only $19 \%$ to $32 \%$ of stable aggregate left after 3 minutes of wet sieving compared to microaggregates where stability ranged from $85 \%$ to $90 \%$. Among the five tillage systems studied, both stable micro and macroaggregate ranged as follows: greater in NT, ST, and CP compared with MP and DR. In this study, changes in aggregate stability with increase in time of wetting up to four hours showed that both micro and macroaggregates had similar trend but different magnitude of stability. Thus, microaggregates were less affected during the wetting and sieving process than macroaggregates (Six et al. 2000) for a continuous sieving of four hours.

The results of micro and macroaggregate decay as a function of time for different tillage treatments are presented in figure $2 \mathrm{a}$ and $2 \mathrm{~b}$. Soil aggregate decay for all tillage systems follows the same trend and is well described by the exponential power function of $\mathrm{y}=\mathrm{b}\left(\mathrm{x}^{\mathrm{a}}\right)$, where $a$ is the slope. All functions had $r^{2}$ values near 1 , which implies that the power function is the best fit for describing aggregate stability over time for each tillage system. For microaggregates, all tillage systems showed almost the same slope, where no significant differences between tillage systems slopes a were observed $(p<$ $0.05)$ (table 1). Slope values are in the range of -0.248 and -0.287 , which suggests that soil microaggregates decreased at similar rates over time regardless of tillage treatment. The percentage of stable microaggregates observed between 12 and 240 minutes for tillage treatments was in the following order: $\mathrm{NT}>\mathrm{ST}>\mathrm{CP}>\mathrm{DR}>\mathrm{MP}$. This trend was not observed at 3 and 6 minutes. In a study by Ouatarra et al. (2008), wet sieving over a period of time from 5 to $240 \mathrm{~min}$ utes showed microaggregates as more stable than macroaggregates when subjected to continuous wetting. In their study, the 5 minute period was not used to determine microaggregates stability. In this study, the higher percentage of stable microaggregates observed in the NT and ST treatments compared with CP and DP is consistent with the findings of Ouattara et al. (2008), where macroaggregate stability with reduced tillage was $87 \%$ and $26 \%$ higher in sandy loam soils classified as Ferric Lixisols and soils of loamy texture classified as Ferric or Gleyic Luvisols soils (FAO 1998), respectively, compared with the annual ox-plowed plots.

Macroaggregate stability as a function of time shows a different trend for the same tillage systems over time (figure $2 \mathrm{~b}$ ). The macroaggregate decay functions' slope coefficients for all tillage systems were not significantly different (table 1). This suggests that the rate of disintegration of macroaggregate was the same when soil aggregates were subjected to continuous and prolonged wetting conditions. This can be attributed to the quality of soil carbon (C) as labile and less highly processed $\mathrm{C}$ in macroaggregates, which can be easily dissolved during the wetting process regardless of the tillage system (Six et al. 1999). After 72 minutes of wet sieving, a steady trend of macroaggregate stability for all tillage systems began to establish. This may indicate that macroaggregate stability was not significantly affected by the additional wetting process after 72 minutes of wet sieving.

In contrast, soil microaggregate stability decay function of different tillage systems over time showed significantly lower slope values compared with macroaggregates. The lower slope values of microaggregate decay function indicate greater stability of microaggregates compared with macroaggregates, which disintegrate faster over time. This is consistent with the percentages of microaggregates for the various tillage systems as compared with macroaggregates at different times (figure 1). This can be attributed to the protection of microaggregates as primary units within the macroaggregates, where they are bound together into macroaggregates by transient binding agents (Tisdall and Oades 1982).

Relationship between Soil Aggregate Stability and Soil Organic Carbon Content. The correlation between aggregate stability percentage of macro and microaggregates and SOC content for all tillage systems was positive $(r=0.65)$, with NT showing the highest aggregate stability percentage (figure 3). The decline in SOC content with increased intensity of tillage was observed compared to the baseline or NT system after 10 years (figure $4 \mathrm{a}$ ). Regardless of tillage system, the findings show that increase in SOC content increased the stability of soil micro and macroaggregates (figure 3). The magnitude of soil aggregate stability associated with NT system was greater than that with other tillage systems as the SOC content increased. It was suggested that organic materials were the major binding agents for aggregate formation and stabilization, especially in Alffisol and Mollisol soils (Oades and Waters 1991). Therefore, the absence of soil disturbance with NT system and the increase in SOC retention and storage, enhanced the formation of macroaggregates, which contributes to the protection of microaggregates (Six et al. 2004). The other possible mechanism that can contribute to the differences between different tillage systems' aggregate stability as related to SOC content is the physical effect of tillage system by exposing microaggregates to biological activities and the loss of readily decomposable $\mathrm{C}$ during tillage operation (Cambardella and Elliott 1992).

As noted above, the continuous decline in SOC content with increase tillage intensity at the top $15 \mathrm{~cm}$ (6 in) depth ranked as follows with NT showing the highest SOC content followed by CP, ST, DR, and MP (figure 4a). The correlation between SOC content and percentage stable aggregates (figure 3) confirmed this observation; lower 


\section{Figure 2}

Kinetics of wet soil (a) microaggregate and (b) macroaggregates stability decay over time at the top $15 \mathrm{~cm}$ of five tillage systems of a 10 year long-term tillage and crop rotation study.

(a)

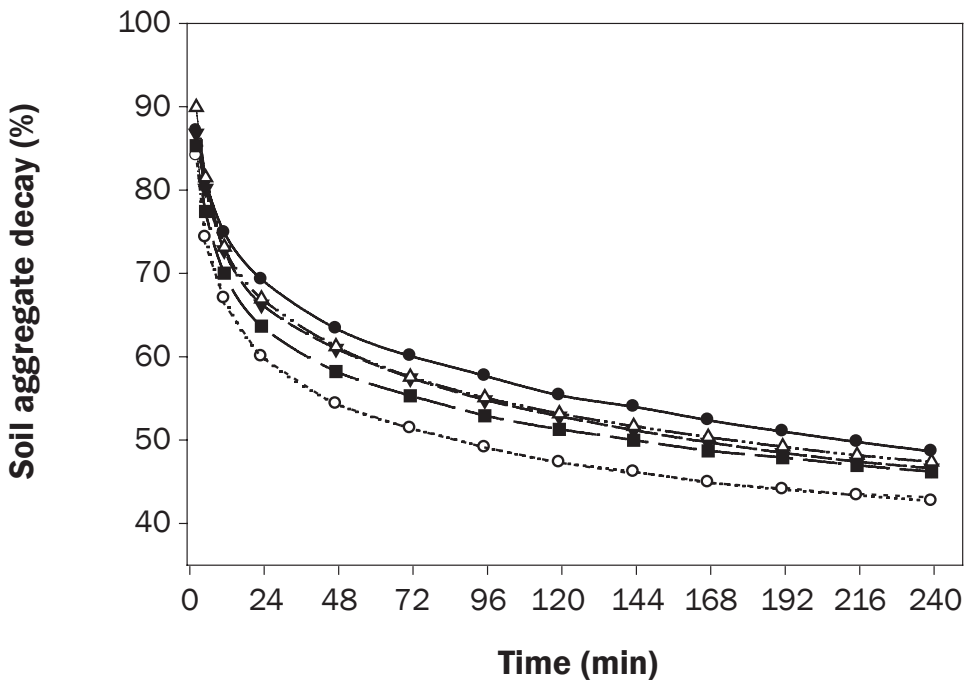

(b)

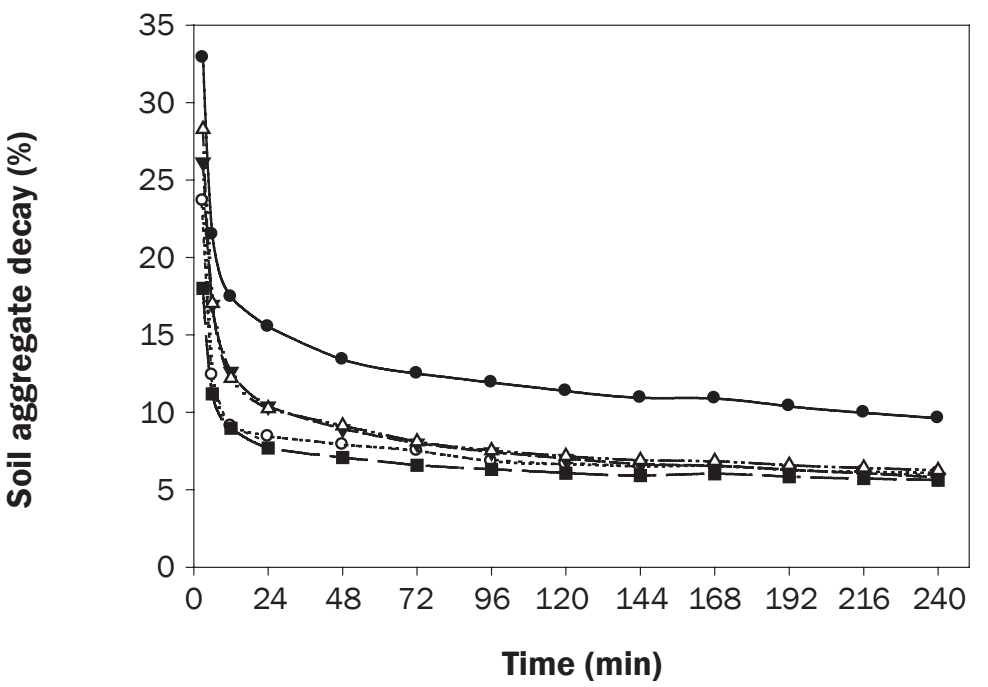

Legend

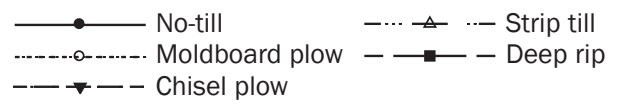

SOC content, especially in conventionally tilled soils, resulted in less stable aggregates compared with that for NT soils. More than 10 years since the establishment of this study, the only significant increase in SOC content at the top $15 \mathrm{~cm}$ (6 in) was observed with NT as compared to the baseline, but STN content was significantly greater than that for the baseline for all tillage systems (figure $4 \mathrm{a}$ and b). Soil tillage manipulates soil nutrient storage and release with rapid mineralization of SOM and the potential loss of SOC and STN from the soil (Chivenge 2007). These changes in the short term can be insignificant, yet SOC content for NT soil aggregates increased over time, consistent with the findings of Sainju et al. (2008) and West and Post (2002). Stable macroaggregates are enriched in new SOC compared with unstable macroaggregates (Gale et al. 2000), especially in relatively undisturbed systems like NT, where new root-derived intraaggregate particulate organic matter is important in stabilizing small macroaggregates.

Although the differences in SOC and STN contents for soil with different tillage treat- ments were not significantly different $(p<$ $0.05)$, all tillage systems' SOC and STN contents at the top 0 to $15 \mathrm{~cm}$ ( 0 to 6 in) depth were different from that for the baseline. This finding is not consistent with Mathew et al. (2012) that long-term NT results in higher SOC and STN contents at the top soil depth compared with conventional tillage.

Relationship between Soil Moisture Content and Soil Organic Carbon Content. The relationship between SOC and soil moisture contents is presented in figure 5, where a strong positive correlation was observed $(r=0.70)$ at the top $15 \mathrm{~cm}$ (6 in) depth. The change in soil SOC content as influenced by different tillage systems at the top $15 \mathrm{~cm}$ (6 in) affected soil moisture content, where significant increase in soil moisture content was observed as the SOC content increased. Even though differences in SOC content were not significant between all tillage systems, NT SOC increased significantly compared to SOC content of the baseline over 10 years (figure 4a). Therefore, the increase in SOC, especially with NT may be a contributing factor to the increase in moisture holding capacity. This positive correlation between SOC and soil moisture content can also be linked to the increase in soil aggregate formation and stability (figure 3) (Six et al. 2000; Causarano et al. 2008), which promotes large moisture storage capacity (Rawls et al. 2003) that is essential for reducing soil temperature (Lakshmi et al. 2003), enhancing soil C accumulation (Moreno et al. 2006). The relationships between soil moisture content and SOC content and aggregate stability demonstrated in these findings highlight the role of SOC in improving soil quality.

\section{Summary and Conclusions}

The stability of both micro and macroaggregates over time was influenced by tillage systems during the wetting process. The influence of a prolonged wetting process has more detrimental effects on macroaggregates with different tillage systems, especially with conventional tillage systems as the SOC loss increased due to mechanical destruction of soil structure. These findings support the hypothesis that an NT system creates better soil conditions for stabilization and protection of macroaggregates when the wetting process continues for a long time. The findings also demonstrated that microaggregates are less influenced by type of tillage sys- 
Figure 3

Correlation between wet micro and macroaggregate stability percentage and soil organic carbon (SOC) content with five tillage systems of a 10 year long-term tillage and crop rotation study.

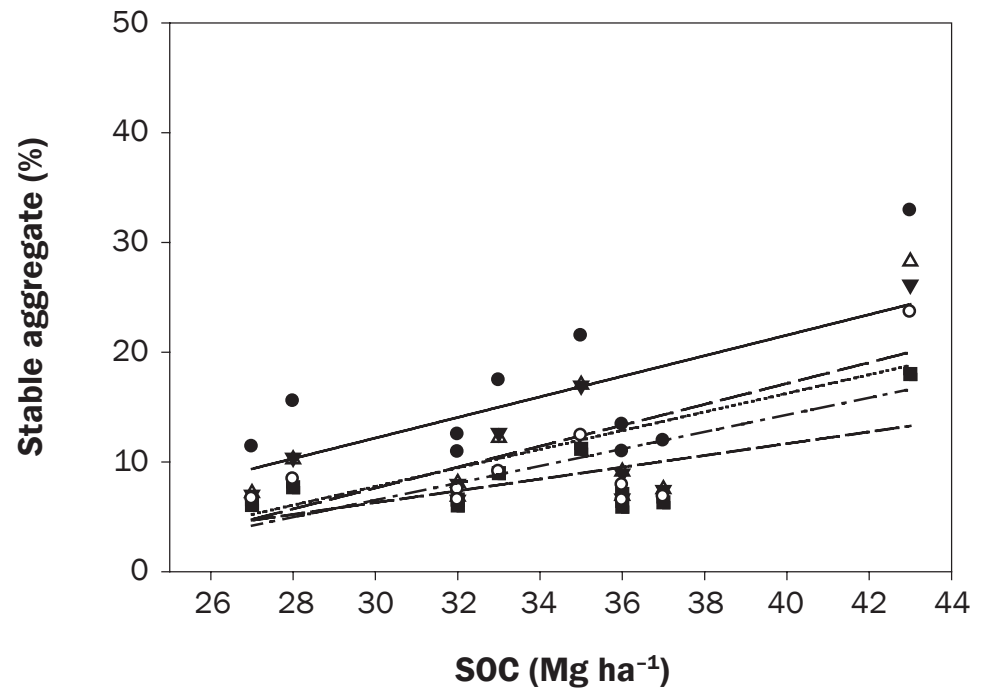

Legend

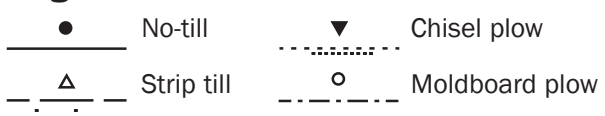

- _- Deep rip tem. The increase in SOC content did not only contribute to the increase in aggregate stability, but it caused an increase in soil moisture storage capacity. The value of these findings is highly significant in documenting the long-term stability of aggregate fractions under continuous wet condition and the value of adopting NT to mitigate weather changes and volatility of rain intensities and durations. The findings also demonstrate the negative effect of conventional tillage not only on SOC decline, but also the weakening of soil aggregate formation and strength under continuous wet conditions, which can lead to other negative effects such as sediment loss and water quality concerns.

\section{References}

Al-Kaisi, M.M., and X. Yin. 2005. Tillage and crop residue effect on soil carbon and carbon dioxide emission in corn-soybean rotations. Journal of Environmental Quality $34: 437-445$

Beare, H.M., M.I. Cabrera, P.F. Hendrix, and D.C. Coleman. 1994. Aggregate-protected and unprotected organic pools in conventional and no-tillage soils. Soil Science Society of America Journal 58:787-795.

Blake, G.R., and K.H. Hartge. 1986. Bulk density. In Methods of Soil Analysis Part. 1 Physical and Mineralogical Methods,

\section{Figure 4}

(a) Soil organic carbon and (b) soil total nitrogen at the top $15 \mathrm{~cm}$ with five tillage systems of a 10 year long-term tillage and corn-soybean rotation. (a)

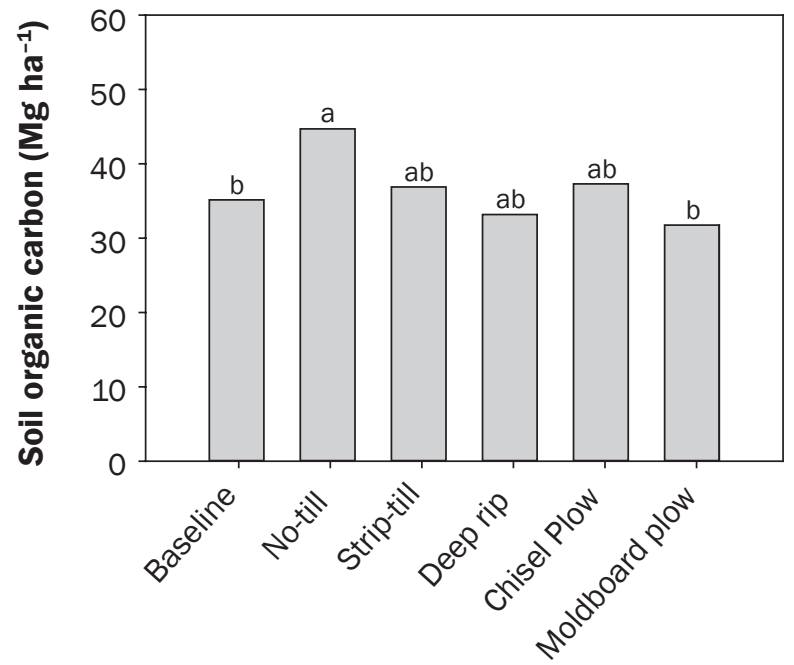

Tillage (b)

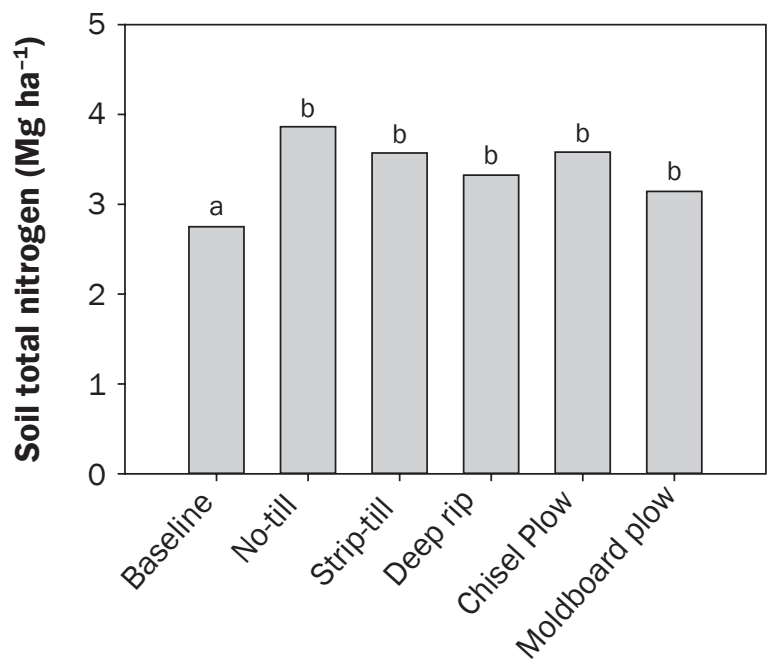

Tillage
Legend

Legend

$\square$ SOC 0 to $15 \mathrm{~cm}$ 


\section{Figure 5}

Correlation between averages soil moisture content and soil organic carbon content at the top $15 \mathrm{~cm}$ of a 10 year long-term five tillage systems in corn-soybean rotation study.

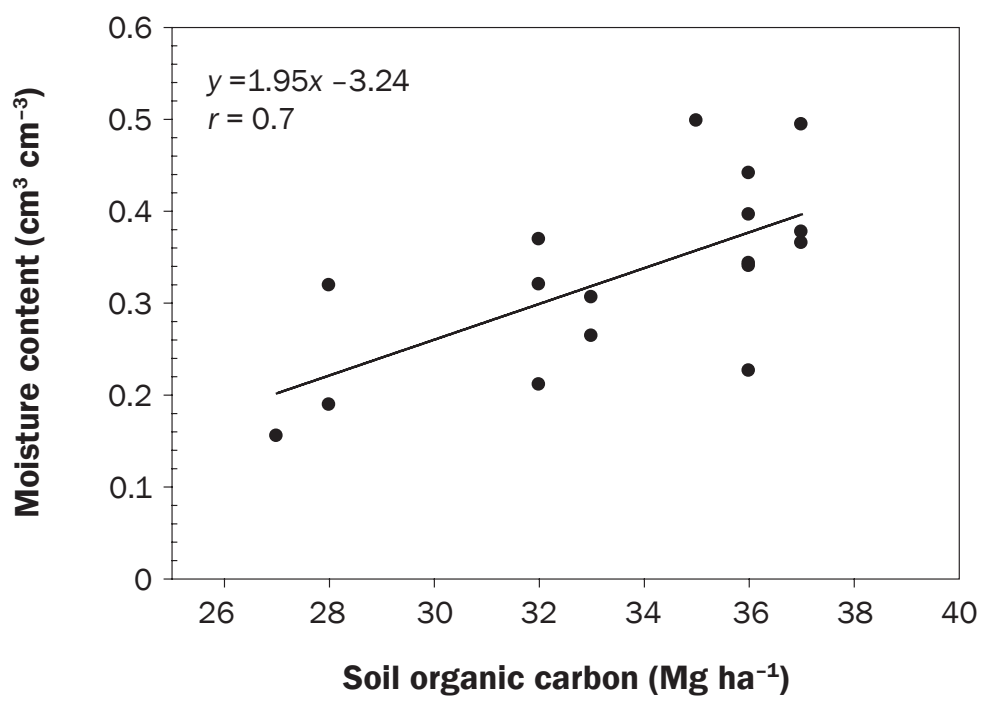

ed. A. Kluste, 363-375. Madison, WI: Agronomy Society of America and Soil Science Society of America.

Cambardella, C.A., and E.T Elliot. 1992. Particulate soil organic-matter changes across a grassland cultivation sequence. Soil Science Society of America Journal 56:777-783.

Causarano, H.J., A.J. Franzluebbers, J.N. Shaw, D.W. Reeves, R.L. Raper, and C.W. Wood. 2008. Soil organic carbon fractions and aggregation in the southern piedmont and coastal plain. Soil Science Society of America Journal 72(1):221-230.

Chivenge, P.P., H.K. Murwira, K.E. Giller, P. Mapfumo, and J. Six. 2007. Long-term tillage and residue management on soil carbon stabilization: Implications for conservation agriculture on contrasting soils. Soil \& Tillage Research 94:328-337.

Curaqueo, G., E. Acevedo, P. Cornejo, A. Seque, R. Rubio, and F. Borie. 2010. Tillage effect on soil organic matter, mycorrhizal hyphae and aggregates in a Mediterranean agrosystem. Journal of Science and Plant Nutrition 10(1):12-21

Dam, R.F., B.B. Mehdi, M.S. Burgess, C.A. Madramootoo, G.R. Mehuys, and I.R. Callum. 2004. Soil bulk density and yield under eleven consecutive years of corn with different tillage and residue practices in a sandy loam in central Canada. Soil \& Tillage Research $84: 41-53$

De Sanctis, G., P.P. Roggero, G. Seddaiu, R. Orsini, C.H Porter, and J.W. Jones. 2012. Long-term no tillage increased soil organic carbon content of rain-fed cereal systems in a Mediterranean area. European Journal of Agronomy 40:18-27.

Díaz-Zorita, M., J.H. Grove, and E. Perfect. 2005. Soil fragment size distribution and compactive effort effects on maize root seedling elongation in moist soil. Crop Science 45:417-1426.

Donald, R.G., B.D. Kay, and M. Miller. 1987. The effect of soil aggregate size on early shoot and root growth of maize (Zea mays L.). Plant Soil 103:251-259.
FAO. 1998. World Reference Base for Soil Resources. Rome: Food and Agriculture Organization.

Gale, W.J., C.A. Cambardella, and T.B. Bailey. 2000. Rootderived carbon and formation and stabilization of aggregates. Soil Science Society of America Journal 64:201-207.

Garvriliev, R.I. 2003. Quantitative estimation of the thermal conductivity of saturated frozen soils, eds, Phillips, Springman, and Arenson. Permafrost ISBN 9058095827.

Gathala, M. K., J.K. Ladha, V. Kumar, V. Kumar, and P.K. Sharma. 2011. Effect of tillage and crop establishment methods on physical properties of a medium-textured soil under seven-year rice-wheat rotation. Soil \& Water Management \& Conservation 75(5):1851-1862.

Guzman, J., and M. Al-Kaisi. 2011. Reconstructed prairies age and landscape position effect on selected soil properties in south central Iowa. Journal of Soil and Water Conservation 66 (3):183-191, doi:10.2489/jswc.66.3.183.

Green,V.S., M.A. Cavigeli, T.H. Dao, and D.C. Flanagan. 2005. Soil physical properties and aggregate-associated C, N and $\mathrm{P}$ distributions in organic and conventional cropping systems. Soil Science 170(10):822-831.

Ismail, I., R.L. Blevins, and W.W. Frye. 1994. Long term no tillage effects on soil properties and continuous corn yields. Soil Science Journal 58:193-198.

Lakshmi,V., T.J. Jackson, and D. Zehrfuhs. 2003. Soil moisturetemperature relationships: Results from two field experiments. Hydrological Processes 17:3041-3057.

Mathew, R.P., Y. Feng, L. Githinji, R. Ankumah, and K.S. Balkcom. 2012. Impact of no-tillage and conventional tillage systems on soil microbial communities. Applied \& Environmental Soil Science 2012(548620)10 doi:10.1155/2012/548620.

Moreno, E., J. M. Murillo, E. Pelegrin, and I.E. Giron. 2006. Long-term impact of conservation tillage on stratification ratio of soil organic carbon and loss of total and active CaCO3. Soil \& Tillage Research 85:86-93.

Oades, J.M., and A.G. Waters. 1991. Aggregate hierarchy in soils. Australian Journal of Soil Research 29:815-828.
Ouattara, K., B. Ouattara, G. Nyberg, M.P. Sédogo, and A. Malmer. 2008. Effects of ploughing frequency and compost on soil aggregate stability in a cotton-maize (Gossypium hirsutum-Zea mays) rotation in Burkina Faso. Soil Use and Management 24:19-28, doi: 10.1111/j.1475-2743.2007.00129.

Perez-Brandán, C., J.L. Arzeno, J. Huidobro, B. Grümberg, C. Conforto, S. Hilton, G. D. Bending, J.M. Meriles, and S. Vargas-Gill. 2012. Long-term effect of tillage systems on soil microbiological, chemical and physical parameters and incidence of charcoal rot by Macrophomina phaseolina (Tassi) Goid in soybean. Crop Protection 40:73-82.

Rawls, W.J.,Y.A. Pachepsky, J.C. Ritchie, T.M. Sobecki, and H. Bloodworth. 2003. Effect of soil organic carbon on soil water retention. Geoderma 116:61-76.

Reijneveld, A., J. van Wensem, and O. Oenema. 2005. Soil organic carbon contents of agricultural land in the Netherlands between 1984 and 2004. Geoderma 152:231-238.

Sainju, U.M., J.D. Jabro, and W.B. Stevens. 2008. Soil carbon dioxide emission and carbon sequestration as influenced by irrigation, tillage, cropping system and nitrogen fertilization. Journal of Environmental Quality 37:98-106.

Saljnikov, E., D. Cakmak, and S. Rahimgdieva. 2013. Soil organic matter stability as affected by land management in Steppe Ecosystem. INTECH Journals, Chapter 10, p.269310. http://dx.doi.org/10.5772/53557.

SAS Institute. 2002. The SAS system for Microsoft Windows. Release 9.1. Cary, NC: SAS Institute.

Six, J., H. Bossuyt, S. Degryze, and K. Denef. 2004. A history on the link between (micro) aggregates, soil biota, and soil organic matter dynamic. Soil \& Tillage Research 79:7-31.

Six, J., E.T. Elliot, and K. Paustian. 2000. Soil macroaggregates turnover and microaggregate formation:A mechanism for $\mathrm{C}$ sequestration under no-tillage agriculture. Soil Biology and Biochemistry 32:2099-2103.

Six, J., E.T. Elliot, and K. Paustian. 1999. Aggregate and soil organic matter dynamics under conventional and no-tillage systems. Soil Science Society of America Journal 63:1350-1358.

Stirzaker, R., J.B. Passiourra, and Y. Wilms. 1996. Soil structure and plant growth: Impact of bulk density and biopores. Plant and Soil 185:151-162.

Tisdall, J.M., and J.M. Oades. 1982. Organic matter and water stable aggregates in soils. Soil Science Journal 33:141-161.

West, T.A., and W.M. Post. 2002. Soil organic carbon sequestration rates by tillage and crop rotation: A global data analysis. Soil Science Society of America Journal 66:1903-1946.

Wright, S.F., and R.L. Anderson. 2000. Aggregates stability and glomalin in alternative crop rotations for the central Great Plains. Journal of Biology and Fertility of Soils. 31:249-253.

Wright, S.F., W.L. Shelver, R.L. Kolberg, and M. West. 2010. Long-term tillage and cropping effects on microbiological properties associated with aggregation in a semi-arid soil. Journal of Biology and Fertility of Soils 47: 157-165. 